rheumatology outpatient clinic between 2000 and 2020 were retrospectively evaluated.

Results: Venous involvement was detected in $17.6 \%(\mathrm{n}: 76)$ patients who were followed up with a diagnosis of BD. $75 \%$ of the patients were male, and their mean diagnosis age was $27.1 \pm 9.9$, disease duration was $14.2 \pm 6.3$ years. While the thrombosis of lower extremity veins, cervical veins, and vena cava were observed in $85.5 \%$ of BD patients, superficial thrombophlebitis was found in $31.6 \%$. Cerebral venous involvement (CVI) was evaluated in cranial involvement. Oral aphthous ulcer was found in $97.4 \%$ of the patients, genital ulcer in $65.8 \%$, pathergy positivity in $44.7 \%$, papulopustular lesion in $34.2 \%$, erythema nodosum in $40.8 \% .27 .6 \%$ of the patients were evaluated for hereditary thrombophilia and $5.3 \%(n: 7)$ had hereditary thrombophilia. Deep venous thrombosis was found in $85.7 \%(6 / 7)$ of these patients, renal artery occlusion in $14.3 \%$, pulmonary artery thrombosis in $14.3 \%$, and cerebral venous thrombosis in $28.6 \%$. Patients with and without venous involvement were compared in terms of clinical findings. A significant difference was observed in terms of retinal vasculitis, artery occlusion, arterial aneurysm, family history for BD and gender. In logistic regression analysis, a significant relationship was observed between venous involvement and gender, family history, retinal vasculitis, artery occlusion, arterial aneurysm (Table1).

Table 1. Comparison of data of patients with and without venous involvement

\begin{tabular}{|c|c|c|c|c|}
\hline & $\begin{array}{c}\text { Venous } \\
\text { Involvement (+) } \\
\text { n:76 }\end{array}$ & $\begin{array}{l}\text { Venous Involvement } \\
\qquad \begin{array}{l}\text { (-) } n: 318\end{array}\end{array}$ & $\mathrm{P}$ & $\mathrm{OR}^{*}(\% 95 \mathrm{Cl})$ \\
\hline Gender & & & 0.000 & 2.78 \\
\hline Female & $19(25)$ & $153(48.1)$ & & $(1.58-4.88)$ \\
\hline Male & $57(75)$ & $165(51.9)$ & & \\
\hline Family History & $4(5.3)$ & $44(13.8)$ & 0.049 & $\begin{array}{c}0.035 \\
(0.12-0.99)\end{array}$ \\
\hline Oral Aphthous Ulcer & $74(97.4)$ & $305(95.9)$ & 0,745 & \\
\hline Genital Ulcer & $50(65.8)$ & $206(64.8)$ & 0,894 & \\
\hline Papulopustular lesion & $26(34.2)$ & $103(32.4)$ & 0,786 & \\
\hline Erythema Nodosum & $31(40.8)$ & $119(37.4)$ & 0,601 & \\
\hline Pathergy & $34(44.7)$ & $151(47.5)$ & 0,772 & \\
\hline Uveitis & $20(26.3)$ & $118(37.1)$ & 0,083 & \\
\hline Retinal Vasculitis & $5(6.6)$ & $6(1.9)$ & 0.036 & $\begin{array}{c}3.66 \\
(1.08-12.33)\end{array}$ \\
\hline Arthritis & $13(17.1)$ & $85(26.7)$ & 0,104 & \\
\hline Artery Occlusion & $6(7.9)$ & $3(0.9)$ & 0.002 & $\begin{array}{c}8.97 \\
(2.19-36.74)\end{array}$ \\
\hline Arterial Aneurysm & $7(9.2)$ & $8(2.5)$ & 0.013 & $\begin{array}{c}3.93 \\
(1.37-11.20)\end{array}$ \\
\hline $\begin{array}{l}\text { Gastrointestinal } \\
\text { involvement }\end{array}$ & $6(7.9)$ & $11(3.5)$ & 0,111 & \\
\hline Cardiac involvement & $3(3.9)$ & $3(0.9)$ & 0,089 & \\
\hline Cranial involvement & $7(9.2)$ & $17(5.3)$ & 0,282 & \\
\hline
\end{tabular}

* Significant data in logistic regression analysis were presented

Conclusion: Superficial venous thrombosis and deep vein thrombosis are the most frequent vascular involvements in BD patients. Significant correlations exist between $\mathrm{CVI}$ and pulmonary artery involvement (PAI), intracardiac thrombosis and PAI. It should be recalled that lower extremity venous thrombosis is often present in these associations, and even precede them (1).

REFERENCES:

[1] Seyahi E. Behçet's disease: How to diagnose and treat vascular involvement. Best Practice \& Research Clinical Rheumatology. 30 (2016) 279-295

Disclosure of Interests: None declared

DOI: 10.1136/annrheumdis-2021-eular.1144

\section{AB0357 LANDSCAPE REVIEW OF PATIENT-REPORTED OUTCOME MEASURES IN GIANT CELL ARTERITIS}

H. H. Colwell ${ }^{1}$, S. Mathias2, K. Kato ${ }^{3}$, C. E. Najem ${ }^{4}$, A. M. Archer ${ }^{5} .{ }^{1}$ Health Outcomes Solutions, Outcomes Research, Winter Park, United States of America; ${ }^{1}$ Health Outcomes Solutions, Outcomes Research, Winter Park, United States of America; ${ }^{3}$ Janssen Pharmaceutical Companies of Johnson \& Johnson, Patient Reported Outcomes, Raritan, United States of America; ${ }^{4}$ Janssen Pharmaceutical Companies of Johnson \& Johnson, Rheumatology Clinical Research, Spring House, United States of America; 5 Janssen Pharmaceutical Companies of Johnson \& Johnson, Translational Medicine, Spring House, United States of America

Background: Giant cell arteritis (GCA) is a systemic large vessel vasculitis that results in symptoms (e.g., headaches, jaw claudication, fatigue, pain, etc.) that can have multiple negative impacts on an individual's health-related quality of life.

Objectives: To identify important symptoms and impacts experienced by individuals with GCA, develop a conceptual model, and evaluate available patient reported outcome (PRO) measures for appropriateness for inclusion in GCA clinical studies.

Methods: Published literature on disease experience from databases, conference abstracts, and Guidance/OMERACT documents were reviewed. A GCA conceptual model was developed based on the symptoms and impacts identified from this literature and supplemented with clinical input. A detailed review of selected PROs was then conducted to assess concept coverage and gaps to evaluate appropriateness for a GCA population.

Results: Of 245 identified citations, 24 abstracts and 18 articles were reviewed Key symptoms affecting GCA patients (e.g., ischemic and constitutional symptoms) and impacts to the lives of GCA patients (e.g., reduced physical, social and emotional functioning) formed the basis for a GCA conceptual model (see Figure 1).

No GCA-specific PROs were identified. Therefore, the PROs that were used most frequently in GCA clinical studies were reviewed and evaluated. These included the SF-36, FACIT-Fatigue, Patient Global Assessment (PtGA), Multidimensional Fatigue Inventory (MFI), EQ-5D, Health Assessment Questionnaire (HAQ), Brief Illness Perception Questionnaire (BIPQ), and Visual Functioning Questionnaire-25 (VFQ-25). These PROs included some key impacts but did not assess most GCA-specific symptoms (e.g., headaches, fever, etc.). No measures were developed with input from GCA patients and there has been limited evaluation of the measurement properties of these PROs in GCA patients.

The FACIT-Fatigue, SF-36, and the PtGA, which were frequently administered in published GCA studies, measure key GCA concepts such as fatigue, functioning, impact on daily activities and disease status. The measurement properties (reliability, validity, sensitivity to change) have been documented in several other rheumatologic diseases (Table 1).

Conclusion: In the absence of a GCA-specific PRO, the SF-36, FACITFatigue, and PtGA are recommended for use in GCA clinical studies for the assessment of key concepts identified in the literature. Qualitative and quantitative research should be conducted with GCA patients to assess the content validity and measurement properties of these PROs in a GCA population.

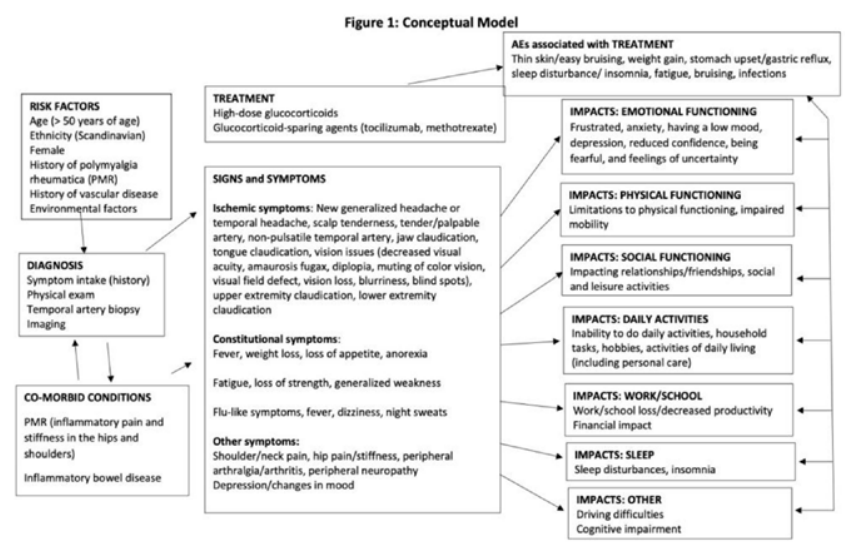


Table 1. Summary of Recommended Measures

\begin{tabular}{|c|c|c|c|}
\hline Description & SF-36 & FACIT-Fatigue & PtGA \\
\hline Type & $\begin{array}{l}\text { Generic, health status } \\
\text { measure }\end{array}$ & $\begin{array}{l}\text { Fatigue and } \\
\text { impact on } \\
\text { function/daily } \\
\text { activities }\end{array}$ & $\begin{array}{l}\text { Measure of } \\
\text { disease } \\
\text { activity }\end{array}$ \\
\hline $\begin{array}{l}\text { Method of } \\
\text { Administration }\end{array}$ & Self/Interviewer & Self/Interviewer & Self \\
\hline \# of Items & 36 & 13 & 1 \\
\hline Recall period & Past 4 weeks/past week & Past 7 days & Varies \\
\hline Scoring & $\begin{array}{l}8 \text { domain scores; } 2 \text { component } \\
\text { summary scores }\end{array}$ & Total score & Total score \\
\hline $\begin{array}{l}\text { Measurement } \\
\text { properties }\end{array}$ & $\begin{array}{l}\text { Measurement properties } \\
\text { demonstrated in other } \\
\text { rheumatologic diseases } \\
\text { (SLE, RA, SpA, and chronic } \\
\text { knee pain); construct validity } \\
\text { demonstrated in a single study } \\
\text { with GCA patients }\end{array}$ & $\begin{array}{l}\text { Measurement } \\
\text { properties } \\
\text { demonstrated in } \\
\text { rheumatologic } \\
\text { populations } \\
\text { including SLE, } \\
\text { PsA, and RA }\end{array}$ & $\begin{array}{l}\text { Select } \\
\text { measurement } \\
\text { properties } \\
\text { have been } \\
\text { demonstrated } \\
\text { in GCA and } \\
\text { other } \\
\text { populations } \\
\text { (RA, TAK, } \\
\text { RP) }\end{array}$ \\
\hline $\begin{array}{l}\text { Concept } \\
\text { coverage }\end{array}$ & $\begin{array}{l}\text { GCA impacts (emotional, physical, } \\
\text { and social functioning, and daily } \\
\text { activities), bodily pain, fatigue }\end{array}$ & Fatigue & $\begin{array}{l}\text { Overall } \\
\text { assessment } \\
\text { of disease } \\
\text { activity }\end{array}$ \\
\hline $\begin{array}{l}\text { Administered in } \\
\text { recent GCA } \\
\text { studies }\end{array}$ & YES & YES & YES \\
\hline
\end{tabular}

$\mathrm{SLE}=$ systemic lupus erythematosus, $\mathrm{SpA}=$ spondyloarthritis, PsA=psoriatic arthritis, $\mathrm{RA}=$ rheumatoid arthritis, $\mathrm{GCA}=$ giant cell arteritis, $\mathrm{TAK}=$ Takayasu's arteritis, $\mathrm{RP}=$ relapsing polychondritis

Disclosure of Interests: Hilary $\mathrm{H}$ Colwell Consultant of: Janssen Pharmaceutical Companies of Johnson \& Johnson, Susan Mathias Consultant of: Janssen Pharmaceutical Companies of Johnson \& Johnson, Kelly Kato Employee of: Janssen Pharmaceutical Companies of Johnson \& Johnson, Catherine E Najem Shareholder of: Johnson \& Johnson, Employee of: Janssen Pharmaceutical Companies of Johnson \& Johnson, Amy M Archer Employee of: Janssen Pharmaceutical C ompanies of Johnson \& Johnson

DOI: 10.1136/annrheumdis-2021-eular.1199

\section{AB0358 ABATACEPT AS A вDMARD IN STEROID-REFRACTORY POLYMYALGIA RHEUMATICA}

E. Toussirot ${ }^{1}$, M. Michaud ${ }^{2}$, D. Wendling ${ }^{3}$, V. Devauchelle-Pensec ${ }^{4} .{ }^{1} \mathrm{CHU}$ de Besançon, INSERM CIC-1431, Besancon, France; ${ }^{2}$ Hôpital Joseph Ducuing, Centre de Compétence Maladies Lysosomales, Toulouse, France; ${ }^{3} \mathrm{CHU}$ de Besançon, Rhumatologie, Besancon, France; ${ }^{4} \mathrm{CHU}$ de Brest, Rhumatologie, Brest, France

Background: polymyalgia rheumatica (PMR) is a chronic inflammatory disorder affecting elderly people. Glucocorticoids (GC) are the mainstay of therapy for PMR. Despite this treatment, the disease may relapse or GC dosage cannot be tapered. Methotrexate (MTX) may be helpful in these cases. Blockade of IL- 6 has an effective steroid-sparing effect in patients with giant cell arteritis (GCA) and may improve the clinical symptoms of patients with PMR. The pathophysiology of PMR still remains uncertain but there are evidences for a participation of Th1 and Th17 lymphocytes. Recently, blockade of the costimulatory pathway by abatacept (ABA) gave favorable results in GCA.

Objectives: to report our experience (efficacy and safety) of ABA in the treatment of patients with isolated PMR who required longstanding $\mathrm{GC}$ and who failed to respond to MTX and/or IL-6 receptor blocking agents.

Methods: a call for observations of all cases of patient with PMR who received at least one dose (SC or IV) of ABA was sent to the members of the French specialist network "Club Rhumatismes \& Inflammation" (CRI: www. cri-net.com)(rheumatologist and internal medicine). Patients must satisfy the EULAR/ACR criteria for PMR and have isolated PMR without associated GCA.

Results: 4 cases were declared during a 12 months period: 2 men and 2 women; age (median [range]): 60.7 [50-68] years; disease duration 30 [7-48] months; duration of GC treatment before starting ABA: 60 [10-72] months.
They all required prednisolone with a daily dosage of $14.5 \mathrm{mg}$ [10-20]. Before ABA administration, they all received MTX while 2 patients were treated by IL-6R inhibitor (tocilizumab 6 months and sarilumab 3 months, respectively) without improvement. ABA was given as a monthly infusion $(10 \mathrm{mg} / \mathrm{kg})$ in one case and subcutaneously (every week) in 3 cases. ABA treatment duration ranged from 3 to 18 months. Two patients responded to the treatment with a progressive decline of DAS-PMR and GC dosage tapering during a 12 month follow-up, while there was no improvement for the 2 others (Table 1). CRP levels also decreased for one responder. The safety was excellent for all. ABA was still maintained in one responder. Among the non-responders, one patient was switched to tocilizumab and the second still received high GC dosage.

Conclusion: ABA may be effective in certain PMR patients who were unable to taper GC, with a good safety profile. A randomized controlled trial is required in order to determine its place in the treatment of PMR and to select the appropriate patients who could potentially benefit from this biological agent.

REFERENCES:

[1] Langford CA et al. Vasculitis Clinical Research Consortium. A Randomized, Double-Blind Trial of Abatacept (CTLA-4Ig) for the Treatment of Giant Cell Arteritis. Arthritis Rheumatol. 2017; 69: 837-845

Table 1. changes in DAS-PMR and CRP levels in 4 patients with PMR while receiving abatacept (M: months; CRP in $\mathrm{mg} / \mathrm{L}$ ).

\begin{tabular}{lccccccccc}
\hline Cases & $\begin{array}{c}\text { DAS- PMR } \\
\text { M0 }\end{array}$ & $\begin{array}{c}\text { DAS- PMR } \\
\text { M3 }\end{array}$ & $\begin{array}{c}\text { DAS-PMR } \\
\text { M6 }\end{array}$ & $\begin{array}{c}\text { DAS -PMR } \\
\text { M12 }\end{array}$ & $\begin{array}{c}\text { CRP } \\
\text { M0 }\end{array}$ & $\begin{array}{c}\text { CRP } \\
\text { M3 }\end{array}$ & $\begin{array}{c}\text { CRP } \\
\text { M6 }\end{array}$ & $\begin{array}{c}\text { CRP } \\
\text { M12 }\end{array}$ \\
\hline $\mathbf{1}$ & 20 & 21 & 21 & NA & 5 & 8.6 & 8.4 & NA \\
$\mathbf{2}$ & 31.1 & 30.5 & NA & NA & 21 & 25 & NA & NA \\
$\mathbf{3}$ & 10.7 & 8.35 & 5 & 13 & 37.2 & 22.7 & 22 & 22 \\
$\mathbf{4}$ & 18 & 22 & 17.2 & 12 & 1.2 & 3.3 & 3.5 & 3 \\
\hline
\end{tabular}

Disclosure of Interests: None declared

DOI: 10.1136/annrheumdis-2021-eular.1246

AB0359
CRANIAL INVOLVEMENT IN BEHÇET'S
DISEASE

Ö. Özdemir Ișlk ${ }^{1}$, S. Şan ${ }^{1}$, A. Yazici ${ }^{1}, A$. Cefle ${ }^{1} .{ }^{1}$ Kocaeli University School of Medicine, Rheumatology, Kocaeli, Turkey

Background: Behçet's disease (BD) is a vasculitic multisystem inflammatory disorder. It may also involve the skin, mucosa, eyes, blood vessels, joints, gastrointestinal system, and central nervous system (CNS).

Objectives: In this study, we aimed to present CNS involvement data in patients followed up with a diagnosis of BD.

Methods: The clinical, demographic, laboratory and medication data of 394 patients who were followed up with a diagnosis of BD in our rheumatology outpatient clinic between 2000 and 2020 were retrospectively evaluated.

Results: CNS involvement was detected in \%5.6(24) patients who were followed up with a diagnosis of BD. $66.7 \%$ of the patients were male, and their mean diagnosis age was $25.1 \pm 8.2$ years, mean CNS involvement age was $28.39 \pm 9.6$ years. Neurological symptoms occurred in an average of 3.3 years after the diagnosis of BD. Parenchymal involvement was present in $54.2 \%$ of the patients with CNS involvement, $45.8 \%$ had cerebral venous thrombosis. Oral apthous ulcer was found in $91.7 \%$ of the patients, genital ulcer in $70.8 \%$, pathergy positivity in $\% 45.8$ papulopustular lesion in $\% 37.5$, erythema nodosum in \%45.8. Patients with CNS involvement had headache, vision loss, diplopia, hemiparesis, epilepsy, proptosis, and ataxic gait and walking difficulty in $66.6 \%, 12.5 \%, 25 \%, 12.5 \%, 8.3 \%, 8.3 \%$ and $12.5 \%$, respectively. Patients with and without CNS involvement were compared in terms of clinical findings and medications. A significant difference was observed in terms of cardiac involvement (Table 1). While one of the 2 patients with cardiac involvement had a thrombus in the right ventricle, the other had pericardial effusion. The patient with cardiac thrombus also had cerebral venous thrombus. Steroid, azathioprine, cyclophosphamide treatments have been used at a higher in patients with CNS involvement. In addition, the patients with parenchymal and cerebral venous involvement were compared in terms of clinical, demographics findings and medications The presence of papulopustular lesions (9.1\% vs $57.1 \%$ ) and pathergy positivity $(18.2 \%$ vs $71.4 \%)$ were higher in patients with parenchymal involvement (p:0.033, p: 0.020, respectively). 